\title{
RESPON PERTUMBUHAN BIBIT KAKAO (Theobrama cacao L) PADA UKURAN WADAH TANAM POLYBAG YANG BERBEDA
}

\author{
Wahyudi ${ }^{1}$, Chairil Ezward ${ }^{2}$, A. haitami ${ }^{3}$ \\ ${ }^{1}$ Jurusan Agroteknologi, Fakultas Pertanian, Universitas Islam Kuantan Singingi \\ Email:wahyudi.uniks@gmail.com ezwardchairil@yahoo.com haitami1982@gmail.com
}

\begin{abstract}
Cocoa (Theobrama cacao $L$ ) is one of the mainstay commodities of plantations, which plays an important role in the national economy. The level of production of cocoa plants is largely determined by the good treatment given during its growth and development. This study aims to determine the growth response of cocoa seedlings at different sizes of polybag planting containers. This research is in the form of a field experiment conducted in Koto Kari Village, Kuantan Tengah District, Kuantan Singingi Regency. The study was conducted for 7 months using a non-factorial randomized block design. Namely various sizes of polybags consisting of 6 levels of treatment, each treatment was repeated in 3 groups so that 18 experimental units were obtained. The treatment given is: Polybag $8 \times 12 \mathrm{~cm}$, Polybag $10 \times 15 \mathrm{~cm}$, Polybag $14 \times 22 \mathrm{~cm}$, Polybag $18 \times 25 \mathrm{~cm}$, Polybag $20 \times 25 \mathrm{~cm}$ and Polybag $25 \times 40 \mathrm{~cm}$. The results of this study were statistically tested with the $F$ test, then if it was significantly different, it was continued with the BNJ test (Honest Significant Difference) at the 5\% level. Parameters observed were plant height $(\mathrm{cm})$, stem diameter $(\mathrm{mm})$ and plant fresh weight (grams). Based on the results of the study, it can be concluded that the best treatment was found in the Polybag $25 \times 40 \mathrm{~cm}$ planting container treatment, plant height $174.67 \mathrm{~cm}$, stem diameter $2.00 \mathrm{~mm}$, plant fresh weight 445.33 grams.
\end{abstract}

Keywords: Growth, Cocoa, Planting container

\begin{abstract}
Abstrak
Tanaman kakao (Theobrama cacao L) merupakan salah satu komoditas andalan perkebunan yang peranannya cukup penting bagi perekonomian nasional. Tingkat produksi tanaman kakao sangat ditentukan oleh baiknya perlakuan yang diberikan selama pertumbuhan dan perkembangannya. Penelitian ini memiliki tujuan untuk mengetahui respon pertumbuhan bibit kakao pada ukuran wadah tanam polybag yang berbeda. Penelitian ini berbentuk percobaan lapangan yang dilakukan di Desa Koto Kari, Kecamatan Kuantan Tengah Kabupaten Kuantan Singingi. Penelitian dilaksanakan selama 7 bulan menggunakan Rancangan Acak Kelompok Non Faktorial. Yaitu berbagai ukuran polybag terdiri 6 taraf perlakuan, masing-masing perlakuan diulang sebanyak 3 kelompok sehingga diperoleh 18 unit percobaan. Perlakuan yang diberikan adalah: Polybag $8 \times 12 \mathrm{~cm}$, Polybag $10 \times 15 \mathrm{~cm}$, Polybag $14 \times 22 \mathrm{~cm}$, Polybag $18 \times 25 \mathrm{~cm}$, Polybag $20 \times 25 \mathrm{~cm}$ dan Polybag $25 \times 40 \mathrm{~cm}$. Hasil penelitian ini diuji secara statistik dengan uji $F$, kemudian bila berbeda nyata dilanjutkan dengan uji BNJ (Beda Nyata Jujur) pada taraf 5\%. Parameter yang diamati adalah tinggi tanaman $(\mathrm{cm})$, diameter batang $(\mathrm{mm})$ dan bobot segar tanaman (gram). Berdasarkan hasil penelitian dapat disimpulkan bahwa perlakuan terbaik terdapat pada perlakuan wadah tanam Polybag $25 \times 40 \mathrm{~cm}$, tinggi tanaman $174,67 \mathrm{~cm}$, diameter batang 2,00 mm, bobot segar tanaman 445,33 gram.
\end{abstract}

Kata kunci: Pertumbuhan, Kakao, Wadah tanam

\section{PENDAhuluan}

Tanaman kakao (Theobrama cacao L) merupakan salah satu komoditas andalan perkebunan yang peranannya cukup penting bagi perekonomian nasional, khususnya sebagai penyedia lapangan kerja, sumber pendapatan dan devisa negara. Bahkan 
Indonesia merupakan negara penghasil kakao terbesar ke-3 dunia setelah Pantai Gading dan Ghana. Dengan melihat kondisi potensi lahan, industri kakao, pasar kakao baik dalam negeri maupun luar negeri memiliki potensi yang cukup baik.

$$
\text { Berdasarkan data Direktorat }
$$

Jenderal Perkebunan (2021) tanaman kakao secara nasional dalam 5 tahun terakhir luas lahan mencapai 1 .658.421 hektar pada tahun 2017, 1 .611.014 hektar pada tahun 2018, 1 .560.944 hektar tahun 2019, 1 .528 .383 hektar tahun 2020, 1.497 .467 hektar tahun 2021.

Berdasarkan data tersebut diatas luas lahan dan produktivitas tanaman kakao dari tahun ke tahun cendrung berpluktuasi. Tingkat produksi tanaman kakao sangat ditentukan oleh baiknya perlakuan yang diberikan selama pertumbuhan dan perkembangannya, terutama selama pertumbuhan awal di pembibitan. Salah satu yang perlu diperhatikan dalam langkah pertama di pembibitan adalah pemilihan ukuran polybag sebagai wadah tempat tumbuh bibit tanaman kakao. Penggunaan ukuran polybag yang digunakan sangat menentukan pertumbuhan akhir bibit tanaman kakao. Wadah tanam polybag yang terlalu kecil dapat mengganggu pertumbuhan akar tanaman kakao, namun wadah tanam polybag yang terlalu besar sangat baik untuk pertumbuhan tanaman kakao, namun tidak efisien dalam penggunaan media tanam yang digunakan.

Ukuran wadah dalam menggunakan media tanam sangat menentukan perkembangan akar tanaman, karena akar akan berkembang dengan baik apabilah ruangan tempat tumbuhnya tidak bermasalah. Perakaran merupakan sandaran utama pada tanaman dalam menunjang aerasi fotosintat dan kerja hormon tumbuhan. Keseimbangan antara perakaran dan tunas tanaman sulit terjadi ketika sistem perakaran dibatasi dalam volume media tumbuh yang sempit.

Berdasarkan ukuran polybag yang digunakan dalam pembibitan tanaman kakao Rahardjo (2011) mengemukakan bahwa ukuran polybag yang dipakai dalam pembibitan tanaman kakao adalah 15 x 20 $\mathrm{cm}$ (umur 4 bulan), $20 \times 30 \mathrm{~cm}$ (umur 5 bulan) dan $25 \times 40 \mathrm{~cm}$ (umur besar dari 5 bulan)

Berdasarkan hasil penelitian yang dilakukan oleh Wasonowati (2010) menunjukkan bahwa perlakuan ukuran polybag berpengaruh nyata terhadap jumlah daun, bobot basah dan bobot kering batang dan daun tanaman tomat. Hasil pengujian terhadap polybag dengan tiga ukuran $30 \mathrm{x}$ $30 \mathrm{~cm}, 30 \times 40 \mathrm{~cm}$, dan $40 \times 40 \mathrm{~cm}$ menunjukkan bobot basah dan bobot kering tertinggi terdapat pada ukuran polybag terbesar 40 x $40 \mathrm{~cm}$.

\section{Tujuan}

Adapun tujuan penelitian ini adalah untuk mengetahui respon pertumbuhan bibit kakao pada ukuran wadah tanam polybag yang berbeda.

\section{METODOLOGI PENELITIAN}

Penelitian berbentuk percobaan lapangan, dimulai dari proses persiapan bahan dan alat, pelaksanaan penelitian, sampai ke pengamatan parameter. Penelitian dilakukan di Kebun Percobaan Fakultas Pertanian Universitas Islam Kuantan Singingi. Penelitian dilaksanakan selama 7 bulan terhitung mulai bulan April sampai Oktober 2019. Bahan yang digunakan adalah: Benih kakao yang diambil dari perkebunan rakyat di Desa Koto Kari Kecamatan Kuantan Tengah, pupuk organik kotoran kambing, polybag, pupuk NPK Mutiara 16:16:16, Dolomit, paku. Alat-alat yang digunakan adalah cangkul, parang, gembor, $\mathrm{pH}$ Meter, gelas ukur $25 \mathrm{ml}$, gunting potong, meteran, handsprayer, timbangan digital serta alat-alat tulis.

Rancangan yang digunakan adalah Rancangan Acak Kelompok (RAK) Non Faktorial. Yaitu beberapa ukuran polybag terdiri 6 taraf perlakuan, masing-masing perlakuan diulang sebanyak 3 kelompok sehingga diperoleh 18 unit percobaan. Setiap unit percobaan terdiri dari 4 tanaman, 3 diantaranya dijadikan sebagai tanaman sampel, dengan demikian jumlah tanaman keseluruhan adalah 72 tanaman. Adapun perlakuannya sebagai berikut: $A=$ Polybag 8 $\mathrm{x} 12 \mathrm{~cm}, \mathrm{~B}=$ Polybag $10 \times 15 \mathrm{~cm}, \mathrm{C}=$ Polybag $14 \times 22 \mathrm{~cm}, \mathrm{D}=$ Polybag $18 \times 25$ $\mathrm{cm}, \mathrm{E}=$ Polybag $20 \times 25 \mathrm{~cm}, \mathrm{~F}=$ Polybag 25 $x 40 \mathrm{~cm}$. Hasil penelitian ini diuji secara statistik pada tabel Anova, apabila F hitung lebih besar dar $F$ tabel maka dilanjutkan dengan uji Beda Nyata Jujur (BNJ) pada taraf $5 \%$.

\subsection{Pelaksanaan Penelitian}

Persiapan tempat penelitian dilakukan dengan cara mengukur lahan dengan ukuran $7 \times 6 \mathrm{~m}$, setelah itu dibersihkan dari gulma dan sampah, gulma disiangi mamakai cangkul, sampah dipungut dan dibuang keluar areal penelitian. Pembuatan naungan dibuat menggunakan kayu sebagai rangkanya, daun kelapa sebagai atapnya, dengan ukuran $6,5 \times 5,5 \mathrm{~m}$, ketinggian 1,5 m 
(dibuat sama tinggi). Persiapan perlakuan wadah tanam diawali dengan cara memberi label perlakuan pada masing-masing polybag. Pemberian label dilakukan dengan menggunakan cat pada masing-masing polybag sesuai perlakuan. Sebelum media tanam tanah dimasukkan dalam polybag terlebih dahulu dilakukan pengukuran $\mathrm{pH}$ menggunakan $\mathrm{pH}$ meter. $\mathrm{pH}$ tanah yang diukur adalah 5,2, maka dilakukan pemberian kapur dolomit sesuai dengan dosis rekomendasi tanah ultisol secara umum, yaitu 2 ton /hektar. Adapun media tanam yang digunakan adalah campuran tanah top soil dengan pupuk kandang kotoran kambing (2:1). Setelah media diisikan pada wadah tanam polybag kemudian di susun pada lahan penelitian dalam naungan dengan susunan sesuai dengan lay out penelitian Jarak tanam antar polybag dilakukan dengan jarak $50 \times 50 \mathrm{~cm}$. Jarak antar blok $100 \mathrm{~cm}$, sedangkan jarak satuan unit percobaan dalam blok $50 \mathrm{~cm}$. Setelah media tanam disusun kemudian didiamkan selama dua minggu sebelum tanam. Penanaman dilakukan terhadap benih yang telah disiapkan sebelumnya. Penanaman dilakukan dengan cara membuat lubang tanam menggunakan tugal kedalaman $3 \mathrm{~cm}$, kemudian benih dimasukkan kedalam lubang tanam dengan jumlah 1 benih untuk setiap polybag, setelah itu benih kembali ditutup dengan menggunakan tanah secara tipis.

\subsection{Pemeliharaan}

Penyiraman dilakukan setiap hari di waktu pagi antara pukul 06.00-09.00 WIB dan sore antara pukul 16.00-17.00 WIB. Penyiraman disesuai kondisi lingkungan yang bertujuan untuk menjaga kelembaban areal pertanaman. Jika hari hujan tidak dilakukan penyiraman. Penyiraman dilakukan dengan menggunakan gembor. Penyulaman dilakukan pada tanaman yang mati, atau pertumbuhannya terganggu. Penyulaman dilakukan dengan menggunakan bibit cadangan yang umurnya sama dengan bibit yang telah ditanam. Penyulaman dilakukan dengan batas waktu maksimal dua minggu setelah tanam. Pemberian pupuk anorganik diberikan 5 kali selama penelitian yaitu pada umur 30, 60, 90,120 dan 150 hari setelah tanam. Adapun pupuk anorganik yang diberikan yaitu pupuk NPK Mutiara 16:16:16. Cara pemberian pupuk anorganik diberikan dengan cara ditugalkan dengan membuat 3 lubang dengan jarak $5 \mathrm{~cm}$ dari pangkal batang kedalaman $5 \mathrm{~cm}$, kemudian pupuk dimasukkan dengan dosis 2 gram untuk setiap tanaman, kemudian ditutup kembali dengan tanah.

\subsection{Penyiangan}

Dilakukan terhadap gulma yang tumbuh di dalam maupun di luar polybag. Penyiangan dilakukan secara manual, yaitu dengan cara mencabut menggunakan tangan. Pengendalian hama dan penyakit dilakukan dengan cara prepentif yaitu melakukan sanitasi lahan, penyemprotan fungisida dithane $\mathrm{M}-45$ dan pestisida decis dilakukan 1 kali dalam 1 bulan dengan dosis $2 \mathrm{~g} /$ liter air.

\subsection{Pengamatan}

\subsubsection{Tinggi tanaman}

Diukur pada tanaman sampel, menggunakan meteran mulai dari leher akar sampai titik tumbuh tertinggi. Diameter batang diukur pada tanaman sampel, menggunakan jangka sorong, yang diukur pada pangkal batang sekitar $2 \mathrm{~cm}$ dari permukaan tanah. Berat basah tanaman diukur pada tanaman sampel, dengan cara mencabut tanaman dari media tanam, kemudian dibersihkan dari kotoran, dan menimbang seluruh bagian tanaman akar, batang dan daun menggunakan timbangan digital. Semua parameter pengamatan di lakukan pada akhir penelitian yaitu pada saat umur tanaman 6 bulan setelah tanam, kemudian dilakukan analisis statistik dan dilanjutakan uji lanjut Beda Nyata Jujur (BNJ) pada taraf $5 \%$.

\section{HASIL DAN PEMBAHASAN}

\section{Tinggi Tanaman (cm)}

Data hasil pengamatan tinggi tanaman bibit kakao setelah dilakukan analisis sidik ragam menunjukan

Tabel 1 : Rerata Tinggi Tanaman Perlakuan Besar Polybag Pada Pembibitan Tanaman Kakao Pada Saat Tanaman Berumur 6 Bulan Setelah Tanam.

\begin{tabular}{lr}
\hline \multicolumn{1}{c}{ Perlakuan } & \multicolumn{1}{c}{ Rerata } \\
\hline A : Polybag $8 \times 12 \mathrm{~cm}$ & $31,33 \mathrm{e}$ \\
B : Polybag $10 \times 15 \mathrm{~cm}$ & $32,67 \mathrm{e}$ \\
C : Polybag $14 \times 22 \mathrm{~cm}$ & $95,00 \mathrm{~d}$ \\
D : Polybag $18 \times 25 \mathrm{~cm}$ & $110,33 \mathrm{c}$ \\
E : Polybag $20 \times 25 \mathrm{~cm}$ & $149,67 \mathrm{~b}$ \\
F : Polybag $25 \times 45 \mathrm{~cm}$ & $174,67 \mathrm{a}$ \\
Kk : $1,8 \%$ & BNJ : 4,17 \\
\hline
\end{tabular}

Keterangan: Angka-angka pada pada kolom yang diikuti huruf kecil yang sama adalah tidak berbeda nyata menurut uji lanjut Beda Nyata Jujur (BNJ) pada taraf 5\%.

Data rerata tinggi tanaman bibit kakao pada Tabel 1 dapat dilihat perlakuan ukuran polybag pengaruh nyata, dimana perlakuan Polybag $25 \times 45 \mathrm{~cm}$ memiliki 
tinggi tanaman yang paling tinggi yaitu $174,67 \mathrm{~cm}$, dan berbeda dengan perlakuan Polybag $20 \times 25 \mathrm{~cm}$ yaitu $149,67 \mathrm{~cm}$, berbeda dengan perlakuan Polybag $18 \times 25$ $\mathrm{cm}$ yaitu $110,33 \mathrm{~cm}$, berbeda dengan perlakuan polybag $14 \times 22 \mathrm{~cm} 95,00 \mathrm{~cm}$, berbeda dengan perlakuan Polybag $10 \times 15$ $\mathrm{cm}$ yaitu $32,67 \mathrm{~cm}$, dan diikuti dengan perlakuan Polybag $8 \times 12 \mathrm{~cm}$ yaitu $31,33 \mathrm{~cm}$ yang tidak berbeda sesamanya.

Berdasarkan rerata tinggi tanaman bibit kakao dapat dilihat semakin besar polybag yang digunakan semakin tinggi tanaman kakao yang dihasilkan. Hal ini disebabkan karena ruangan tempat tumbuh bibit tanaman kakao juga semakin sempurna. Sempurnanya ruangan tempat tumbuh terutama daerah perakaran akan berdampak baik terhadap pemebentukan akar tanaman kakao. Sempurnanya akar yang terbentuk otomatis akan menambah luas permukaan akar. Sempurnya pertumbuhan akar yang terbentuk pada tanaman kakao akan memberikan dampak posistif terhadap suatu pertumbuhan, karena semakin banyak pula akar yang aktif untuk menyerap zat makanan yang terkandung didalam tanah. Dalam hal ini dapat terbukti pada tinggi tanaman yang dihasilan, semakin besar polybag yang digunakan semakin bagus pertumbuhan tinggi tanaman, dan semakin kecil polybag yang digunakan makin rendah hasil tinggi tanaman yang didapatkan.

Pertumbuhan tinggi tanaman terbentuk karena terjadinya proses pembelahan jaringan meristem apikal. Adapun pertumbuhan memanjang yang diakibatkan oleh aktivitas jaringan meristem apikal lazim disebut pertumbuhan primer. Terjadinya proses pembelahan pada meristem pucuk tidak terlepas dari peranan akar dalam menyerap unsur hara yang ada didalam tanah, termasuk dalam proses penyerapan unsur hara Nitrogen yang berpengaruh lansung dalam pembentukan asam amino, amida, protein, kloropil, dan alkaloid, dan bahkan $40-45 \%$ protoplasma tersusun dari senyawa yang mengandung Nitrogen.

Menurut Lindawati et al., (2000) menyatakan bahwa Nitrogen diperlukan untuk memproduksi protein, lemak, dan berbagai persenyawaan organik lainnya. Nitrogen penting dalam hal pembentukan hijau daun yang berguna sekali dalam proses fotosintesis. Klorofil yang tersedia dalam jumlah yang cukup pada daun tanaman akan meningkatkan kemampuan daun untuk menyerap cahaya matahari, sehingga proses fotosintesis akan berjalan lancar. Fotosintat yang dihasilkan akan dirombak kembali melalui proses respirasi dan menghasilkan energi yang diperlukan oleh sel untuk melakukan aktifitas seperti pembelahan dan pembesaran sel yang menyebabkan organ tanaman menjadi lebih panjang termasuk dapat menambah tinggi bibit tanaman kakao pada penelitian ini.

Menurut Fahrudin F (2009) mengemukakan bahwa apabila perakaran tumbuh dengan baik maka pertumbuhan bagian tanaman yang lain juga akan berkembang baik pula, karena akar dapat menyerap unsur hara yang dibutuhkan tanaman dengan sempurna.

\section{Diameter Batang ( $\mathbf{m m})$}

Data hasil pengamatan diameter batang bibit kakao setelah dilakukan analisis sidik ragam menunjukkan bahwa perlakuan ukuran polybag berpengaruh nyata. Rerata hasil pengamatan diameter batang bibit kakao pada taraf $5 \%$ dapat dilihat pada Tabel 2

Tabel 2 : Rerata Diameter Batang Perlakuan Ukuran polybag Pada Pembibitan Tanaman Kakao (mm)

\begin{tabular}{ll}
\hline Perlakuan & Rerata \\
\hline A : Polybag $8 \times 12 \mathrm{~cm}$ & $0,50 \mathrm{~d}$ \\
B : Polybag $10 \times 15 \mathrm{~cm}$ & $0,66 \mathrm{~d}$ \\
C : Polybag $14 \times 22 \mathrm{~cm}$ & $1,00 \mathrm{c}$ \\
D : Polybag $18 \times 25 \mathrm{~cm}$ & $1,43 \mathrm{~b}$ \\
E : Polybag $20 \times 25 \mathrm{~cm}$ & $1,73 \mathrm{a}$ \\
F : Polybag $25 \times 45 \mathrm{~cm}$ & $2,00 \mathrm{a}$
\end{tabular}

Kk : $17,3 \% \quad$ BNJ : 0,61

Keterangan: Angka-angka pada pada kolom yang diikuti huruf kecil yang sama adalah tidak berbeda nyata menurut uji lanjut Beda Nyata Jujur (BNJ) pada taraf $5 \%$

Data rerata diameter batang bibit kakao pada Tabel 2 dapat dilihat perlakuan ukuran polybag pengaruh nyata, dimana perlakuan polybag $25 \times 45 \mathrm{~cm}$ memiliki diameter batang yang paling besar yaitu 2,00 $\mathrm{mm}$, dan diikuti dengan perlakuan polybag $20 \times 25 \mathrm{~cm}$ yaitu $1,73 \mathrm{~mm}$, dan berbeda dengan perlakuan polybag $18 \times 25$ $\mathrm{cm}$ yaitu $1,43 \mathrm{~mm}$, berbeda dengan perlakuan polybag $14 \times 22 \mathrm{~cm}$ yaitu 1,00 $\mathrm{mm}$, berbeda dengan perlakuan polybag 10 x $15 \mathrm{~cm}$ yaitu $0,66 \mathrm{~mm}$, yang diikuti dengan perlakuan polybag $8 \times 12 \mathrm{~cm}$ yaitu $0,50 \mathrm{~mm}$ yang tidak berbeda sesamanya.

Berdasarkan rerata diameter batang tanaman kakao pada Tabel 2 dapat dilihat bahwasannya semakin besar wadah tanam polybag yang digunakan maka semakin besar diameter batang yang dihasilkan, dan begitu juga sebaliknya, semakin kecil wadah tanam polybag yang digunakan maka 
semakin kecil diameter batang tanaman kakao yang dihasilkan. Pertumbuhan diameter batang terjadi akibat pertumbuhan Jaringan meristem lateral atau juga disebut meristem samping, adalah jaringan meristem yang terletak sejajar dengan permukaan organ, contohnya kambium dan kambium gabus. Jaringan meristem ini berfungsi sebagai jaringan yang membelah dan memperbesar diameter batang tanaman. Pertumbuhan jaringan meristem lateral yang menuju arah samping memungkinkan tumbuh besarnya batang tanaman. Pertumbuhan jaringan meristem lateral lazim disebut pertumbuhan sekunder. Oleh karena itu, jaringan ini pun kerap disebut jaringan sekunder.

Diameter batang tanaman kakao yang terbentuk secara sempurna tidak terlepas dari pengaruh tempat tumbuh tanaman kakao. Dalam penelitian ini dapat dibuktikan rerata diameter batang yang dihasilkan semakin besar seiring bertambahnya ukuran polybag yang digunakan dalam pembibitan tanaman kakao. Berkaitan dengan hal tersebut (Muliawati, 2001; Sarief, 1985) mengemukakan bahwa volume media yang baik untuk budidaya tanaman adalah volume media yang mampu menunjang pertumbuhan dan perkembangan suatu tanaman serta mencukupi kebutuhan tanaman akan air dan unsur hara, yang pada akhirnya berpengaruh pada diameter batang yang dihasilkan juga akan semakin baik.

Dalam penelitian lain Humaerah (2013) mengemukan bahwa ukuran wadah pada tanaman padi dengan diameter $40 \mathrm{~cm}$ memberikan jumlah malai yang lebih tinggi dari pada diameter $30 \mathrm{~cm}$. Hal ini logis, sebab wadah yang lebih besar dapat menampung media yang lebih banyak, sehingga unsur hara dan air yang tersedia bagi tanaman juga lebih besar.

Smith, Scott dan Duval, (1998) mengemukakan bahwa pertumbuhan dan perkembangan tanaman dipengaruhi oleh ukuran media dan perpanjangan batas akar. Akar yang tempat tumbuhnya terbatas akan menyebabkan tanaman menjadi kerdil, karena terjadi keterbatasan ruangan tempat akar bisa melakukan pertumbuhannya dengan baik.

\section{Bobot Segar Tanaman (gram)}

Data hasil pengamatan bobot segar tanaman bibit kakao setelah dilakukan analisis sidik ragam menunjukan bahwa perlakuan ukuran polybag berpengaruh nyata. Rerata hasil pengamatan bobot segar tanaman bibit kakao pada taraf $5 \%$ dapat dilihat pada Tabel .

Tabel 3 : Rerata Bobot Segar Tanaman Perlakuan Ukuran Polybag Pada Pembibitan Tanaman Kakao (gram)

\begin{tabular}{lc}
\hline Perlakuan & Rerata \\
\hline A : Polybag $8 \times 12 \mathrm{~cm}$ & $36,00 \mathrm{f}$ \\
B : Polybag $10 \times 15 \mathrm{~cm}$ & $42,66 \mathrm{e}$ \\
C : Polybag $14 \times 22 \mathrm{~cm}$ & $100,00 \mathrm{~d}$ \\
D : Polybag $18 \times 25 \mathrm{~cm}$ & $227,00 \mathrm{c}$ \\
E : Polybag $20 \times 25 \mathrm{~cm}$ & $382,33 \mathrm{~b}$ \\
F : Polybag $25 \times 45 \mathrm{~cm}$ & $445,33 \mathrm{a}$ \\
Kk : $7,8 \%$ & BNJ : 3,43
\end{tabular}

Keterangan: Angka-angka pada pada kolom yang diikuti huruf kecil yang sama adalah tidak berbeda nyata menurut uji lanjut Beda Nyata Jujur (BNJ) pada taraf 5\%.

Data rerata berat basah bibit kakao pada Tabel 3 dapat dilihat perlakuan ukuran polybag pengaruh nyata, dimana perlakuan polybag $25 \times 45 \mathrm{~cm}$ memiliki berat basah tanaman yang paling berat yaitu 445,33 gram, dan berbeda dengan perlakuan polybag $20 \times 25 \mathrm{~cm}$ yaitu 382,33 gram, berbeda dengan perlakuan polybag $18 \times 25$ $\mathrm{cm}$ yaitu 227,00 gram, berbeda dengan perlakuan polybag $14 \times 22 \mathrm{~cm}$ yaitu 100,00 gram, berbeda dengan perlakuan polybag 10 $x 15 \mathrm{~cm}$ yaitu 42,66 gram, dan berbeda dengan perlakuan polybag $8 \times 12 \mathrm{~cm}$ yaitu 36,00 gram.

Berdasarkan rerata bobot segar tanaman kakao pada tabel 3 dapat dilihat semakin besar wadah tanam polybag yang digunakan maka semakin berat bobot tanaman yang dihasilkan. Poorter, Buhler, Dusschoten, Climent, dan Postma (2012) mengemukakan bahwa adanya pengaruh ukuran wadah tanam terhadap pertumbuhan tanaman, dimana dalam hal ini bisa meningkatkan biomasa tanaman sebanyak $43 \%$.

Bobot segar tanaman merupakan salah satu parameter yang sering digunakan untuk mempelajari pertumbuhan tanaman. Bobot segar tanaman merupakan bobot tanaman setelah dipanen dari media tanam dan dibersihkan dari kotoran sebelum tanaman tersebut layu dan kehilangan air, kemudian dilakukan proses penimbangan dengan timbangan digital. Selain itu bobot segar tanaman merupakan total bobot tanaman mulai dari akar, batang dan daun yang menunjukkan hasil aktivitas metabolik tanaman itu sendiri.

Pertumbuhan berat basah tanaman yang dihasilkan tidak terlepas dari pengaruh dari masing-masing wadah tanam yang digunakan. Semakin sempuran ruangan tempat tumbuh tanaman maka akan 
semakin sempurna perkembangan akar tanaman, dimana hal ini akan berdampak baik dalam hal penyerapan hara yang berada didalam tanah. Ketika tanaman memperoleh ruangan tumbuh yang memadai, pertumbuhan akar terjadi sangat sempurna sehingga tidak terjadi keterbatasan pertumbuhan akar ataupun ada akar yang saling menekan antara satu dengan yang lainnya. Berkaitan dengan sempurnanya pertumbuhan akar maka akan berpengaruh baik terhadap bobot segar tanaman yang juga merupakan gambaran dari fotosintesis selama tanaman melakukan proses pertumbuhan.

Pembentukan akar yang sempurna akan berpengaruh lansung terhadap proses penyerapan unsur hara yang ada didalam tanah. Ketersediaan unsur hara yang berperan penting sebagai sumber energi sehingga tingkat kecukupan hara berperan dalam mempengaruhi biomassa dari suatu tanaman. Syekfani (2002) mengemukakan bahwa unsur hara yang tersedia dapat diserap tanaman dengan baik akan berdampak terhadap pembentukan daun sebagai organ fotosintesis. Karena itulah pertumbuhan daun lebih lebar dan fotosintesis terjadi lebih banyak. Hasil fotosintesis inilah yang digunakan untuk membuat sel-sel akar, batang dan daun sehingga dapat mempengaruhi bobot segar tanaman kakao yang dihasilkan dalam penelitian ini. Berkaitan dengan unsur hara, hal ini ditambahkan oleh Tjionger, M. (2006) mengemukakan bahwa faktor ketersediaan unsur yang dapat diserap oleh tanaman secara sempurna dapat berpengaruh pada pertumbuhan dan perkembangan tanaman sehingga berpengaruh pada berat segar tanaman.

Berkaitan dengan akar, Irwan (2005) mengemukakan bahwa pertumbuhan akar yang baik akan mendukung pertumbuhan tanaman itu sendiri, karena pada dasarnya akar merupakan salah satu organ tanaman yang digunakan untuk menyimpan air dan biomasa dari tanah yang kemudian akan di distribusikan pada tanaman yang nantinya akan digunakan untuk proses metabolisme pada tanaman itu sendiri.

\section{KESIMPULAN DAN SARAN}

\section{Kesimpulan}

Berdasarkan hasil penelitian dapat disimpulkan bahwa perlakuan terbaik terdapat pada perlakuan wadah tanam Polybag $25 \times 40 \mathrm{~cm}$, dengan parameter terbaik tinggi tanaman $174,67 \mathrm{~cm}$, diameter batang 2,00 mm, bobot segar tanaman 445,33 gram.

\section{Saran}

Untuk mendapatkan pertumbuhan bibit tanaman kakao secara sempurna terutama untuk bibit yang berumur 6 bulan disarankan menggunakan polybag dengan ukuran 25x $40 \mathrm{~cm}$

\section{DAFTAR PUSTAKA}

[1] Direktorat Jenderal Perkebuna. 2021. Statistik Perkebunan Indonesia. Jakarta.

[2] Fahrudin, F. 2009. Budidaya caisim (Brassica juncea L.) menggunakan ekstrak teh dan pupuk kascing. Skripsi. Jurusan Budidaya Pertanian. Universitas Sebelas Maret. Surakarta.

[3] Humaerah, A,D. 2013. Budidaya Padi (Oryza sativa) dalam wadah dengan berbagai Jenis Pupuk Pada Sistem Tanam yang Berbeda. Jurnal Agribisnis, Vol. 7, No. 2, Desember 2013, [ 199 210 ]

[4] Irwan, dkk. 2005. Pengaruh Dosis Kascing dan Bioaktivator Terhadap Pertumbuhan dan Hasil Tanaman Sawi (Brassicajuncea L.) yang dibudidayakan secara organik. Jurnal Pertanian. Bandung: Jurusan Budidaya Pertanian Fakultas Pertanian UNPAD.

[5] Lindawati, N., Izhar dan H. Syafria. 2000. Pengaruh pemupukan nitrogen dan interval pemotongan terhadap produktivitas dan kualitas rumput lokal kumpai pada tanah podzolik merah kuning. JPPTP 2(2): 130-133.

[6] Muliawati, E.S. 2001. Kajian Tingkat Sarapan Hara, Pertumbuhan dan Produksi Sambilito (Andrographis paniculata Ness.) Pada Beberapa Komposisi Media Tanam dan Tingkat Pengairan. Prosiding Simposium Nasional II Tumbuhan Obat dan Aromatik APINMAP. Bogor.

[7] Poorter, H., J. Buhler, D. V. Dusschoten, J. Climent, and J. A. Postma. 2012. Pot size matters: a meta-analysis of the effects of rooting volume on plant growth. Journal Compilation by CSIRO, Functional Plant Biology Vol. 39 (839850). 
[8] Rahardjo., P. 2011. Menghasilkan Benih dan Bibit Kakao Unggul. Penebar Swadaya. Jakarta.

[9] Smith, N., D. Scott and J. R. Duval. 1998. The effect of container size. HortTechnology. Vol. October-December $8(4)$.

[10] Syekhfani. 2002. Arti penting bahan organik bagi kesuburan tanah. Jurnal Penelitian Pupuk Organik.

[11] Tjionger's, M. 2009. Esensialitas Air bagi Pertumbuhan dan Produksi Tanaman. http://www.tanindo.com

[12] Wasonowati, C. 2010. Peningkatan Produksi dan Kualitas Tomat (lycopersicon esculentum) Dengan Sistem Budidaya Hidroponik. Jurnal Rekayasa. Volume 3. Nomor 2. Tahun 2010. 